\title{
The Economics of Climate - Resilient Development - A Book Review
}

\author{
Mohamad Buheji \\ Correspondence: Founder - International Institute of Inspiration Economy, Bahrain. \\ Received: May 8, 2018 \\ doi:10.11114/afa.v4i2.3313 \\ Accepted: May 24, 2018 \\ Available online: May 27, 2018 \\ URL: https://doi.org/10.11114/afa.v4i2.3313
}

Fankhauser, S., \& McDermott, T. (2016). The Economics of Climate-Resilient Development, E.Elgar.

\section{Introduction}

The "Economics of Climate-Resilient Development" present a comprehensive mitigation plan to avoid future socio-economic crisis. The authors foresight that unless strategies are adapt effectively and efficiently today by the different communities and specially in the developing low income countries, the world would be vulnerable to economic shocks that never been experienced before.

The book can be considered unique since it linked the economic development with the techniques of adaptation. It coincides with work the reviewer published about resilience economy where approaches for enhancing people and communities are explained in order to reach the minimum expected adaptability and flexibility. Buheji (2018a, 2018b).

However, the work of Fankhauser and McDermott (2016) greatly focus on climate change, as the main challenge of economic development. The work would be greater if the editors ensure more inclusion and details on the nature of human being journeys.

The issue of poverty covered in the book is a good example of foresighted socio-economic risk that needs to be mitigated to avoid deterioration due to many conditions that mostly would be uncontrollable due external unforeseen factors. In an earlier work, these factors were seen the cause for more complexity of the business models, which required proactive resilient practices, Buheji (2017).

\section{Resilient Development Opportunities}

Choosing resilience smart alternatives that would help to reduce greenhouse gas emission and managing residual climate risks and this is supported by a later studies (Buheji, 2018a). Education, good institution and access to credit as per Fankhauser and McDermott (2016) are considered some of the resilient alternatives.

However, one would debate that poverty is the biggest societal challenge of the $21^{\text {st }}$ century, as there are many other factors that compete for this causality, besides the climate challenge, such as non-communicable diseases and the rising gap between north and south. The book brings in collection of opportunities that can be tackled in order to increase future opportunities.

\section{Adaptation as a Measure of Countries Capacity}

The book treats adaptation to climate change as an issue of climate-resilient development, rather than as a bespoke set of activities (flood defences, drought plans, and so on), combining climate and development challenges into a single strategy. The authors study the different vulnerabilities of developing countries to climate risks and what approaches can help to manage the disruption of the socio-economic trends. The book is well structured with concepts that can be easily followed by action plans.

The intention of coping with climate risks and locking its vulnerability helps to define future opportunities for investors. This piece of knowledge work can help investors assess climate-resilient developments in structured and scientific way.

The editors tried to connect the paper in a way that they would holistically present economic solutions and adaptation plans for managing climate change according to prioritized list. The lesson learned from climate-resilient cities presented in this book encourage decision makers to develop more instruments for climate-resilient development.

\section{Conclusion}

The "Economics of Climate-Resilient Development" is a very important visionary book for low income countries policy makers.

This book teaches us that developments for economic resilience requires us to focus on issues that would influence any 
progress or to mitigate those issues that prevent positive outcome. Thus issues of demographic change need to be studied in developing countries in order to see how it affects its resilience capacity, i.e. in case of climate disasters. One could consider that this book is important for those who are passionate about future foresight of the socio-economic perspective which the world still need many studies to catch up with it major expected risks and turbulances, as mentioned in Buheji (2018c).

\section{References}

Buheji, M. (2018a) Role of Empathetic Engineering in Building More Resilient Green Economy. Case Study on Creating Resilient Self Sufficient Food Security Programs in Middle East. Advances in Social Sciences Research Journal, 5(3) 148-157. https://doi.org/10.14738/assrj.53.4280

Buheji, M. (2018b) Understanding the Power of Resilience Economy: An Inter-Disciplinary Perspective to Change the World Attitude to Socio-Economic Crisis, AuthorHouse, UK.

Buheji, M. (2018c) Practices of Future Foresight in Management of Non-Communicable Diseases -An Early Attempt towards Focusing on 'Foresight Economy' Labs. Advances in Social Sciences Research Journal, 5(4), 344-355. https://doi.org/10.14738/assrj.54.4490

Buheji, M. (2017) Understanding Mechanisms of Resilience Economy- Live Application on a Complex Business Model. Advances in Social Sciences Research Journal, 4(14), 52-64. https://doi.org/10.14738/assrj.414.3484

\section{Copyrights}

Copyright for this article is retained by the author(s), with first publication rights granted to the journal.

This is an open-access article distributed under the terms and conditions of the Creative Commons Attribution license which permits unrestricted use, distribution, and reproduction in any medium, provided the original work is properly cited. 